UDC 330.341.1:502.34

JEL Classification: L83, A19, R1 1

DOI: 10.15587/2312-8372.2019.161206

\section{Kharenko D. Dyshkantiuk 0., Salamatina 5 ., Khalilova-Chuvaeva Iu., Kovalenko L.}

\title{
RESEARCH OF THE GASTRONOMIC BRAND OF ODESA AND PRACTICAL RECOMMENDATIONS FOR SOLVING KEY PROBLEMS
}

Дана робота була спрямована на дослідження процесу формування гастрономічного бренду для посилення привабливості туристичної дестиначії. Формування конкурентоспроможнього гастрономічного бренду є ефективною стратегією в боротьбі за міжнародні ринки, забезпечуючи стабільний туристичний потік і економічний розвиток регіону. Об'єктом дослідження є гастрономічний бренд мультикультурної туристичної дестинацї на прикладі міста Одеси (Україна). Однією із найбільших проблем при формуванні гастрономічного бренду Одеси є недостатня взаємодія його основних складових. У иьому процесі взаємодіі повинні брати участь усі зацікавлені сторони й учасники ринку. Крім того, в м. Одеса ще не розроблена ефективна стратегія для формування регіонального гастрономічного бренду. Необхідно визначити основних учасників гастрономічного життя міста, їх роль у формуванні бренду та сформувати стратегію взаємовигідного розвитку. В результаті застосування методів контент-аналізу та експертного інтерв'ювання був зроблений висновок про великий нереалізований потенціал гастрономічного бренду Одеси як на міжнародному, так і на національному рівні. У тому числі було встановлено, що ресторанний бізнес і гастрономічні фестивалі є вкрай важливими елементами у формуванні гастрономічного бренду, як джерело гастрономічної культури. Були виявлені ключові проблеми, пов'язані з формуванням гастрономічного бренду міста. Для їх рішення було висунуто ідею зі створення гастрономічних карт-путівників міста Одеси, які проінформують туристів і жтелів міста про гастрономічне життя регіону. Дані інформаційні системи дозволять усім учасникам ринку ефективно взаємодіяти між собою. Також були розроблені шляхи формування бренду на основі культурних і кулінарних традицій міста та регіону. Практична иінність проведеного дослідження полягає в тому, що воно може виступати базою для подальших досліджень і сформувати ефективну стратегію просування міста Одеси як туристичної дестинації.

Ключові слова: гастрономічний бренд, гастрономічний туризм, формування бренду дестинацій, туристична дестинація.

\section{Introduction}

The struggle of territories for a place in the international tourist market is becoming more acute, therefore, issues of branding destinations are given a lot of attention to both theorists and practitioners. It is the gastronomic component of the tourist product that is the most important factor shaping the tourist image of a destination in terms of the economy of impressions [1]. To date, the features of various types of gastronomic branding have not been sufficiently studied, so this issue is relevant. Thus, in the works [2, 3], researchers note many deep links between gastronomy and tourism. In [4, 5] it is noted that the local cuisine is a powerful tool in the struggle for the consumer in the market of tourist services and an important component of the brand of the city, region, country. The search for authenticity has become a popular motive for travel, and gastronomy is a significant source for the formation of a territory's identity, an important marker of a tourist destination, which contributes to the creation of a «sense of place» [1,6]. In terms of multiculturalism and the rigorousness of their own unique dishes and products, one must choose a special way of building the gastronomic brand of the city - to form a brand not on the basis of gastronomic achievements, but on the basis of myths, the history of the city, its cultural characteristics, traditions. So, the object of this research is the gastronomic brand of a multicultural tourist destination on the example of the city of Odesa (Ukraine). And the aim of research is analysis of the components of the Odesa gastronomic brand and development of practical proposals for solving key problems in shaping the tourist attractiveness of destinations.

\section{Methods of research}

To identify [7] the most popular Internet platforms among travelers, the most popular tourist portals Google. com, Booking.com, TripAdvisor.com and some local web sites were studied and analyzed. The analysis was carried out for the presence of references to restaurants in Odesa reviews related to the city: culture, cuisine, history.

In particular, within the framework of this work, another content analysis was carried out [8], connected with the study of the content sites of travel companies that occupy leading positions in the Google search system. Content analysis was directed to the point of mentioning restaurants in advertising tours in Odesa.

As part of this study, the authors chose the method of expert interview. A deep semi-structured interview style 
was chosen, since in this case it is possible, based on the data heard, to get more in-depth information from the respondent. In the framework of such an interview is the ability to use certain information as a reference, as well as to connect the obtained data in the research process. The authors have developed a list of specific questions in the interview guide format.

The authors also conducted an expert survey in which 35 experts were interviewed. The experts include:

- heads and leading experts of specialized organizations working in the field of gastronomy, including those aimed at tourists. Experts of restaurants who could potentially participate in the formation of Odesa gastronomic brand were interviewed;

- representatives of the hotel and tourism business.

As well as experts of hotels of various price categories with a restaurant service.

For processing the obtained data as a research result, specialized software was used to analyze the qualitative data of Atlas.ti and SPSS [9].

\section{Research results and discussion}

It should be noted that within the framework of this publication it is difficult to provide detailed information on the analysis of expert interviews, but on the whole - the opinions of the experts were consistent and indicated a consensus on the development of the gastronomic component of the Odesa brand. In the course of the expert survey conducted by the authors and the analysis of interview data [10], two components of the gastronomic brand were formulated, which can create the attractiveness of the city within the framework of various types of tourism.

The first component of Odesa gastronomic brand is «Odesa cuisine». The historical period of the 18th and 20 th centuries arouses the interest of Odesa in the world. In Odesa, there is every reason to develop a gastronomic component - the rich history of the period from the 18th to the 21st century, architectural monuments, museums and art collections of the Soviet era, religious places of the times of the USSR. For tourists from the post-Soviet space, important nostalgic memories are present in the theme of Odesa cuisine, and for tourists from other countries this gastronomic component will also be interesting.

The basic principles of the formation of the «Odesa cuisine» brand:

- animated accompaniment of food intake, with immersion into the atmosphere of Odesa catering establishments;

- except for interior renovation, serving, etc. also, it is necessary to pay attention to the restoration of Odesa branded catering establishments.

The second component - «Odesa is the gastronomic gate of Ukraine». In multinational Ukraine there are a large number of ethnic cuisines. It often happens that a tourist only visits Kyiv and Lviv in Ukraine, but it would be more interesting for such a tourist to get some idea of the whole country. An interesting way to explore the local culture is getting to know the local, authentic cuisine. The authors propose to create gastronomic festivals, exhibitions, presentations of cuisines of the peoples of Ukraine. Such an «ethnic portfolio» will emphasize the role of the Odesa region as the representation of the entire country, in which 133 (out of 134) nationalities living in Ukraine live. The formation of this component is natural, since Odesa has historically been a city that connects many cultures and traditions. Creating such a culinary diversity will allow the tourist, who visits only Odesa, to get an idea of the diversity of Ukraine. Different cuisines can be included in the ethnic portfolio, for example: Ukrainian, Russian, Hebrew, Bulgarian, Romanian, Balkan, etc.

Based on all the analyzed data and the words of experts, it is possible to conclude that the gastronomic life of Odesa is quite multifaceted and has many sections.

The gastronomic brand is built on the basis of the gastronomic culture that is present in the Odesa region [10]. It is difficult to build a brand without a base for it. Despite all the achievements of Odesa in the field of gastronomy, the basis for creating a brand has not yet been formed, to attract a large number of foreign tourists, but it has great potential (Fig. 1). At the moment, the restaurant industry has the greatest potential, as from all the gastronomic resources (food, dishes, staff, restaurant chefs), Odesa has a sufficient number of catering establishments, including restaurants. Undoubtedly, there are some dishes and products that are typical for Odesa, but they are not so obvious and are mostly known only to city residents and tourists from the countries of the former USSR.

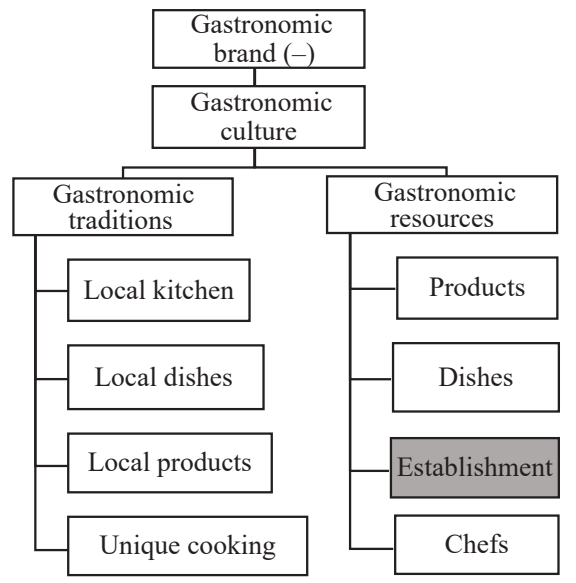

Fig. 1. The structure of the gastronomic brand and catering place

In Odesa, there is a gastronomic potential, at the moment it is in development, restaurant culture is gaining momentum, and the interest of local residents and tourists in the Odesa cuisine is steadily growing. Chefs and restaurateurs actively inform the public about gastronomic innovations, and locals are happy to introduce visitors to the peculiarities of local cuisine. The presence of a large number of restaurant portals, awards, festivals and restaurants in general makes it possible to build a gastronomic brand of Odesa.

In Odesa there is a great potential for the formation of a gastronomic destination brand [10]:

- cultural and historical heritage (Odesa has always been a multinational city. Also, Odesa is a port city, there is a constant population circle, traditions and products. All this creates a gastronomic variety);

- various types of restaurants (by concept, by kitchen, by average);

- desire of participants in this market to form such a brand. 
Interviewing experts allow to single out several reasons why the formation of a gastronomic brand is complicated and the influence of restaurants on the city's brand is weak:

- lack of qualified personnel with sufficient experience (scam artists);

- lack of local products, seasonality (for fish dishes). Problems with access to fresh fruits and vegetables

12 months a year;

- underdevelopment of gastronomic culture in the subconscious of local residents.

Practical solutions to these problems exist. First, it is necessary to popularize the profession of a cook, a few years ago this profession within Ukraine was considered the lot of losers. It is necessary to open culinary schools, conduct master classes and organize festivals where chefs can show their professionalism, thereby increasing the prestige of the profession and declare themselves not in the international arena. Restaurateurs are expected to provide all the conditions for creativity and improvement of their own skills. The problem with local and fresh products is already actively being addressed. In restaurants they create an author's menu that depends on the products that are in the kitchen here and now, product manufacturers are trying to establish uninterrupted production of products, for example, the production of their own cheese or meat. In the opinion of the authors, it is possible to create an association of restaurants on purchases to reduce costs.

The development of gastronomic culture is happening quite quickly. To raise interest in this area of life, it is necessary to hold festivals, contests, awards, make up ratings. People need to convey that a trip to a restaurant does not have to be timed to coincide with an important event, new formats of institutions that are designed for different life situations are opening. The public should be informed that on inspection of the authors, various media and social media are actively doing.

The problem with the lack of a base for the formation of a gastronomic brand can be solved by focusing on the atmosphere of the city, on those characteristics that describe the modern gastronomic image of Odesa: a cafe, live music, communication, traditional Odesa cuisine. The only way to help the development of Odesa gastronomic brand is informing the public about the existence of a gastronomic culture. In particular, it is noted that in most cases restaurants are the starting point, they serve as a platform for the implementation of ideas.

\section{Conclusions}

In this research, approaches have been developed to determine the specifics of the formation of gastronomic brands of various types of territories, namely multicultural cities on the example of the city of Odesa (Ukraine). Recognizing the importance of the tourist gastronomic brand, the authors attempt to develop proposals to enhance the tourist attractiveness of Odesa as an example of a multicultural city, a major cultural center that has a rich history and traditions. This study is of practical importance, since it allows to create new accents for the promotion of Odesa as a gastronomic, unique destination. This is expressed, in particular, in the active formation of cultural and tourist clusters, an integral part of which is creative restaurants, which revive the traditions of the former religious institutions in Odesa. The idea of forming the gastronomic brand of Odesa in a new, nontraditional form is key to the development of a tourist destination.

\section{References}

1. Pine B. J., Gilmore J. H. Welcome to the experience economy // Harvard Business Review. 1998. Vol. 76, Issue 4. P. 97-105.

2. Bessiere J., Tibere L. Traditional food and tourism: French tourist experience and food heritage in rural spaces // Journal of the Science of Food and Agriculture. 2013. Vol. 93, Issue 14. P. 3420-3425. doi: http://doi.org/10.1002/jsfa.6284

3. Henderson J. C. Food tourism reviewed // British Food Journal. 2009. Vol. 111, Issue 4. P. 317-326. doi: http://doi.org/ 10.1108/00070700910951470

4. Hjalager A. M. What do tourists eat and why? Towards a sociology of gastronomy and tourism // Tourism. 2004. Vol. 52, Issue 2. P. 195-201.

5. Richards G. Gastronomy: an essential ingredient in tourism production and consumption? // Tourism and Gastronomy. 2002. Vol. 11. P. 3-20.

6. Scarpato R., Daniele R. New global cuisine: tourism, authenticity and sense of place in postmodern gastronomy // Food Tourism Around The World. 2003. P. 296-313. doi: http:// doi.org/10.1016/b978-0-7506-5503-3.50020-8

7. Using Deep Learning to Predict Sentiments: Case Study in Tourism / Martin C. A. et. al. // Complexity. 2018. Vol. 2018. P. 1-9. doi: http://doi.org/10.1155/2018/7408431

8. Fuchs M., Höpken W., Lexhagen M. Business intelligence for destinations // Advances in Social Media for Travel, Tourism and Hospitality. 2017. P. 290-310. doi: http://doi.org/ 10.4324/9781315565736-24

9. Robinson R. N. S., Getz D. Profiling potential food tourists: an Australian study // British Food Journal. 2014. Vol. 116, Issue 4. P. 690-706. doi: http://doi.org/10.1108/bfj-02-2012-0030

10. Research of the gastronomic brand of tourist destination / Kharenko D. et. al. // Technology Audit and Production Reserves. 2018. Vol. 3, Issue 5 (41). P. 15-21. doi: http://doi.org/ 10.15587/2312-8372.2018.135484

Kharenko Dmytro, PhD, Associate Professor, Department of Hotel and Restaurant Business, Odessa National Academy of Food Technologies, Ukraine, e-mail: Kharenko1980@gmail.com, ORCID: http://orcid.org/0000-0001-7978-3287

Dyshkantiuk Oksana, PhD, Associate Professor, Department of Hotel and Restaurant Business, Odessa National Academy of Food Technologies, Ukraine, e-mail: dyshkantyuk.oksana@gmail.com, ORCID: http://orcid.org/0000-0001-9812-1916

Salamatina Svitlana, PhD, Associate Professor, Department of Hotel and Restaurant Business, Odessa National Academy of Food Technologies, Ukraine, e-mail: salamatina-svetlana@i.ua, ORCID: http://orcid.org/0000-0002-1584-2265

Khalilova-Chuvaeva Iuliia, PhD, Associate Professor, Department of Hotel and Restaurant Business, Odessa National Academy of Food Technologies, Ukraine, e-mail: julik6446@gmail.com, ORCID: http://orcid.org/0000-0002-1935-7793

Kovalenko Liliia, Assistant, Department of Hotel and Restaurant Business, Odessa National Academy of Food Technologies, Ukraine, e-mail:ivychuklilia@gmail.com,ORCID: http://orcid.org/0000-00021330-0702 